\title{
SURVEI KEPADATAN POPULASI DAN INTENSITAS SERANGAN HAMA KEPIK PENGHISAP BUAH KAKAO (Helopeltis spp.) PADA TANAMAN KAKAO (Theobroma cacao L.) DI KABUPATEN LAMPUNG TIMUR
}

\section{THE SURVEY OF POPULATION DENSITY AND ATTACK INTENSITY OF COCOA PODS SUCKER (Helopeltis spp.) IN THE COCOA (Theobroma cacao L.) PLANT IN THE DISTRICT EAST LAMPUNG}

\author{
Ayu Mega Pravita*, Lestari Wibowo, Agus M Hariri, Purnomo \\ Jurusan Agroteknologi Fakultas Pertanian Universitas Lampung \\ Jalan Prof. Dr. soemantri Brojonegoro No.1 Bandar Lampung 35145 \\ *E-mail:ayumega290@gmail.com
}

\begin{abstract}
Cocoa (Theobrema cacao L.) is one of the plantation which plays an important role in the national economy, especially as a provider of employment, a source of income and foreign exchange. There are several obstacles in cocoa cultivation, one of which is the low level of productivity. The low level of productivity is caused by many factors, one of which is the presence of pest. One of the main pests on the cocoa plant is the cocoa pod sucker (Helopeltis sp.). This study aims to determine population density and intensity of the cocoa pod sucker (Helopeltis sp.) On cocoa (Theobroma cacao L.) in several districts in East Lampung Regency. This research was conducted in September 2018, conducted in three sub-districts in East Lampung Regency. This research method was carried out by survey, by directly observing Helopeltis spp. existing in each sample plant. The results showed that the population density of Helopeltis sp. in Margatiga District, 0.19 head / fruit, 0.06 head / fruit in Sukadana District, and 0.16 head / fruit in Sekampung Udik. The population density of Helopeltis sp. in the three sub-districts there is no significant difference. The intensity of damage to cocoa pods in Margatiga District was 45.58\%, 22.00\% in Sukadana District, and 22.42\% in Sekampung Udik District. Helopeltis attacks on cocoa pods in the three districts were not significantly different.
\end{abstract}

Keywords: Helopeltis spp., Population density, Theobroma cacao

\begin{abstract}
ABSTRAK
Kakao (Theobrema cacao L.) merupakan salah satu komoditas perkebunan yang peranannya cukup penting bagi perekonomian nasional, khususnya sebagai penyedia lapangan kerja, sumber pendapatan, dan devisa negara. Terdapat beberapa kendala dalam budidaya tanaman kakao salah satunya adalah tingkat produktivitas yang rendah. Rendahnya tingkat produktivitas ini disebabkan oleh banyak faktor salah satunya adalah adanya organisme pengganggu tanman (OPT). Hama utama pada tanaman kakao salah satunya kepik pengisap buah (Helopeltis sp.). Penelitian ini bertujuan untuk mengetahui kepadatan populasi dan intensitas serangan hama kepik penghisap buah (Helopeltis sp.) pada tanaman kakao (Theobroma cacao L.) di beberapa Kecamatan di Kabupaten Lampung Timur. Penelitian ini dilakukan pada bulan September 2018, dilaksanakan di tiga kecamatan di
\end{abstract}


Kabupaten Lampung Timur. Metode penelitian ini dilakukan dengan survei, dengan mengamati secara langsung hama Helopeltis spp. yang ada pada setiap tanaman sampel. Hasil penelitian menunjukkan bahwa Kepadatan populasi Helopeltis sp. di Kecamatan Margatiga yaitu 0,19 ekor/buah, di Kecamatan Sukadana 0,06 ekor/ buah, dan di Kecamatan Sekampung Udik 0,16 ekor/buah. Kepadatan populasi Helopeltis sp. di tiga kecamatan tersebut tidak berbeda nyata. Intensitas kerusakan buah kakao pada Kecamatan Margatiga yaitu 45,58\%, di Kecamatan Sukadana 22,00\%, dan di Kecamatan Sekampung Udik 22,42\%. Serangan Helopeltis pada buah kakao di tiga kecamatan tersebut tidak berbeda nyata.

Kata kunci: Helopeltis spp ., Kepadatan populasi, Theobroma cacao

\section{PENDAHULUAN}

Kakao (Theobroma cacao L.) merupakan salah satu komoditas perkebunan yang peranannya cukup penting bagi perekonomian nasional, khususnya sebagai penyedia lapangan kerja, sumber pendapatan, dan devisa negara, selain itu kakao juga berperan dalam mendorong pengembangan wilayah dan agroindustri.

Perkebunan kakao di Indonesia mengalami perkembangan cukup pesat dalam kurun waktu 5 tahun terakhir. Perkembangan luas areal perkebunan kakao meningkat dengan tingkat pertumbuhan rata-rata $8 \%$ per tahun dan saat ini mencapai 1.691.942 ha dengan nilai produksinya mencapai 688.345 ton/tahun, yang sebagian besar $87,4 \%$ dikelola oleh rakyat dan selebihnya oleh perkebunan besar negara serta perkebunan besar swasta (Direktorat Jenderal Perkebunan, 2017).

Daerah penghasil biji kakao di Indonesia salah satunya adalah Provinsi Lampung, yang merupakan daerah penghasil biji kakao rakyat terbesar ketiga di Pulau Sumatera setelah Sumatera Barat dan Aceh, dengan produksi dan produktivitas masing-masing sebanyak 22.0617 ton dan $897 \mathrm{~kg} /$ ha pada tahun 2013. (Direktorat Jenderal Perkebunan, 2015).
Di Indonesia, budidaya kakao (Theobroma cacao L.) terus dikembangkan seiring dengan meningkatnya permintaan konsumsi dalam negeri maupun ekspor. Namun demikian pengembangan kakao mengalami hal-hal yang kurang menguntungkan seperti rendahnya mutu biji dan produktivitas yang disebabkan oleh hama dan dapat menurunkan produksi hingga 90\% (Lim, 1992; dan Anshary, 2002 dalam Anshary, 2009).

Hama utama pada tanaman kakao diantaranya hama penggerek buah kakao (Conopomorpha cramerella) dan kepik pengisap buah (Helopeltis sp.). Hama penghisap buah Helopeltis sp. merupakan hama yang berperan penting dalam menimbulkan kerusakan pada buah maupun tunas muda dengan cara menusuk dan menghisap. Ciri serangannya antara lain kulit buah ada bercak-bercak hitam (kecoklatan) dan kering, pertumbuhan buah terhambat, buahkaku dan sangatkeras serta bentuknya mengkerut dan buah kecil, kering, lalu mati. Serangan pada buah muda menyebabkan matinya buah tersebut, sedangkan serangan pada buah berumur sedang mengakibatkan terbentuknya buah abnormal. Akibatnya daya hasil dan mutu buah kakao menurun sebanyak 50\%. (Wardoyo, 1988 dalam Atmadja, 2003). 
Tujuan dari penelitian ini adalah untuk mengetahui kepadatan populasi dan intinsitas serangan hama kepik penghisap buah (Helopeltis sp.) pada tanaman kakao (Theobroma cacao L.) di beberapa kecamatan di Kabupaten Lampung Timur.

\section{BAHAN DAN METODE}

Penelitian ini dilakukan pada bulan September 2018, dilaksanakan di tiga kecamatan di Kabupaten Lampung Timur, yaitu Kecamatan Margatiga, Kecamatan Sukadana, dan Kecamatan Sekampung Udik. Penelitian ini dilaksanakan dengan metode survei. Lokasi pengamatan yaitu di Kabupaten Lampung Timur pada 3 kecamatan yaitu Kecamatan Margatiga, Kecamatan Sukadana, dan Kecamatan Sekampung Udik. Setiap kecamatan diambil sampel dua desa dan pada setiap desa diamati tiga kebun. Dengan demikian kebun yang menjadi sampel pengamatan 18 kebun. Setiap kebun diamati 10 tanaman yang diambil secara diagonal pada kebun. Setiap tanaman diamati lima buah sampel bagian tanaman. Kriteria tanaman sampel ialah tanaman kakao yang telah berproduksi.

\section{HASIL DAN PEMBAHASAN}

Hasil pengamatan di Kecamatan Margatiga, Kecamatan Sukadana, dan Kecamatan Sekampung Udik di Kabupaten Lampung Timur diperoleh hasil bahwa kepadatan populasi dan intensitas serangan Helopeltis sp. di tiga kecamatan tersebut tidak berbeda secara signifikan (Tabel 1). Kepadatan populasi Helopeltis sp. di ketiga lokasi berkisar 0,06 sampai 0,19 ekor/buah. Kepadatan populasi ini cukup rendah, karena tidak semua buah yang diamati ditemukan Helopeltis sp. baik nimfa maupun imago. Intensitas kerusakan akibat serangan Helopeltis sp. di Kecamatan Margatiga 45,58\%, pada Kecamatan Sukadana 22,00\%, pada Kecamatan Sekampung Udik 22,42\%.

Rendahnya kepadatan populasi yang teramati dapat disebabkan oleh beberapa hal antara lain perilaku dari Helopeltis sp. Helopeltis sp. aktif pada pagi

Tabel 1. Kepadatan populasi dan intensitas serangan Helopeltis sp. pada tanaman kakao di Kecamatan Margatiga, Sukadana, dan Sekampung Udik

\begin{tabular}{ccc}
\hline Kecamatan & Kepadatan populasi (ekor/buah) & Intensitas serangan (\%) \\
\hline Margatiga & 0,19 & 45,58 \\
Sukadana & 0,06 & 22,00 \\
Sekampung Udik & 0,16 & 22,42 \\
\hline Fhitung & $1,59^{\text {tn }}$ & $2,78^{\text {tn }}$ \\
\hline
\end{tabular}

Tabel 2. Kepadatan populasi dan intensitas serangan Helopeltis sp. pada tanaman kakao di Kecamatan Margatiga

\begin{tabular}{ccc}
\hline Desa & Kepadatan populasi (ekor/buah) & Intensitas serangan (\%) \\
\hline Nabang Baru & 0,24 & 38,83 \\
Surya Mataram & 0,13 & 52,33 \\
\hline
\end{tabular}


hari pukul 06.00-07.00 WIB (Siswanto dkk., 2009). Pada saat matahari sudah bersinar penuh serangga ini dan berlindung di balik daun yang rimbun. Keberadaan Helopeltis sp. tidak selalu ada di buah dan kemungkinan ada di daun dan ranting. Dengan demikian data yang diperoleh menunjukkan rendahnya populasi Helopeltis sp. pada buah. Serangan Helopeltis sp. dapat ditunjukkan dengan gejala kerusakan yang ditimbulkan oleh Helopeltis sp. Gejala buah kakao yang terserang Helopeltis sp. ditandai dengan bercak-bercak cekung berwarna cokelat muda, yang selanjutnya akan berubahmenjadi kehitaman (Gambar 1).

Pengamatan intensitas serangan dilakukan dengan observasi langsung dengan cara mengamati tiap-tiap buah yang dijadikan sampel penelitian, tiap buah diamati seksama dan apabila terdapat bercakbercak bekas tusukan Helopeltis sp. maka dapat dipastikan buah tersebut telah terkena serangan hama ini. Dan intensitas serangannya dapat dibedakan dengan beberapa kriteria serangan yaitu tanpa serangan, serangan ringan, serangan sedang, serangan berat, dan

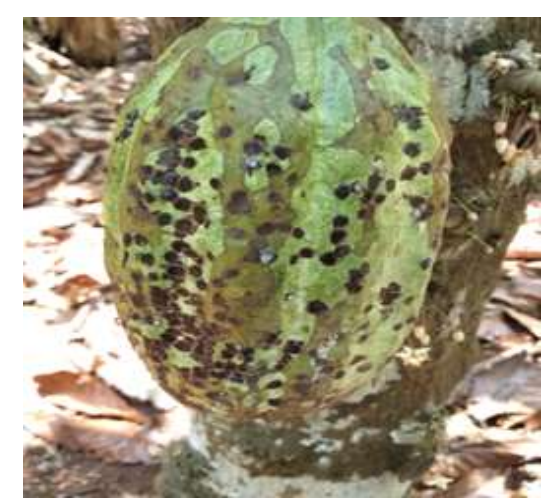

Gambar 1. Gejala serangan Helopeltis sp. pada buah kakao di Desa Surya Mataram kecamatan Margatiga serangan sangat berat (Tabel 1). Pada serangan berat, seluruh pucuk dan permukaan buah muda dipenuhi oleh bekas tusukan yang berwarna hitam. Serangan ini mengakibatkan pucuk menjadi layu dan mati, sehingga menghambat pembentukan buah dan juga dapat menyebabkan buah gugur (Sulistyowati, 2015 dalam Utami dkk., 2017).

Hasil pengamatan intensitas kerusakan buah kakao akibat serangan Helopeltis sp. pada kecamatan Margatiga 45,58\%, kecamatan Sekampung Udik 24,42\%, dan kecamatan Sukadana 22,00\%. Perbedaan besarnya intensitas kerusakan pada ketiga kecamatan tersebut sangat dipengaruhi oleh sistem budidaya dan perawatan tanaman kakao. Pada perkebunan kakao di kecamatan Margatiga terlihat intensitas kerusakan tertinggi, karena perawatan pada kebun kurang maksimal dengan melakukan pemangkasan apabila tinggi tanaman sudah mencapai $3 \mathrm{~m}$ atau daun sudah terlihat rimbun. Pada tanaman kakao dilakukan pemangkasan sekali dua minggu, pemangkasan cabang yang tidak produktif, tumbuh ke

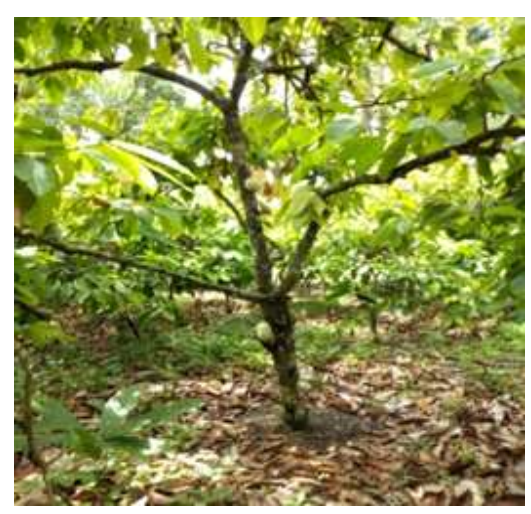

Gambar 2. Kebun kakao tidak terawat di desa Surya Mataram 
arah dalam, menggantung, atau cabang kering, menambah kelembaban dan dapat mengurangi intensitas matahari bagi daun. Pemangkasan pemeliharaan dilakukan dengan cara memotong cabang-cabang sekunder dan tersier yang tumbuhnya kurang dari 40 $\mathrm{cm}$ dari pangkal cabang primer atau sekunder. Cabang-cabang demikian bila dibiarkan tumbuh akan membesar sehingga semakin menyulitkan ketepatan pemangkas. Di samping itu pemangkas semakin sukar dilaksanakan dan semakin merugikan tanaman kakao tersebut (Karmawati dkk., 2010).

Di Kecamatan Margatiga pengamatan dilakukan di desa Nabang Baru dan Surya Mataram. Pengamatan populasi dan intensitas kerusakan Helopeltis sp. (Tabel 2).

Hasil pengamatan kepadatan populasi pada desa Nabang Baru dan Surya Mataram relatif nyata sedangkan data intensitas kerusakan pada desa Surya Mataram lebih tinggi dibandingkan dengan desa Nabang Baru. Tingginya intensitas kerusakan yang diakibatkan oleh Helopeltis sp. yaitu adanya keadaan

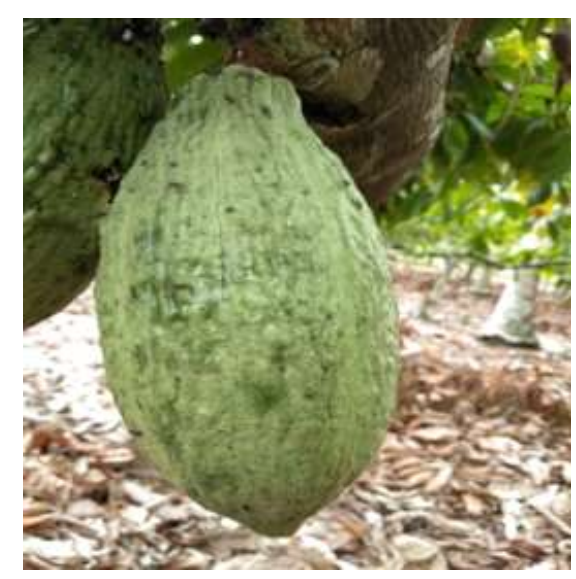

Gambar 3. Semut hitam (Dolichoderus thoracicus) pada buah kakao kebun yang sudah tidak terawat (Gambar 2).

Kebun kakao di Surya Mataram terlihat tidak terawat, dimana banyak gulma yang tumbuh secara liar, kebun terlalu rimbun (tidak dilakukan pemangkasan), dan tidak dilakukan pemupukan (tanaman tumbuh tidak subur). Keadaan ini dapat mendukung perkembangan hama karena banyak gulma yang menjadi inang alternatifnya sehingga perlu dilakukan pembersihan gulma di sekitar pertanaman kakao. Gulma merupakan organisme pengganggu tanaman di perkebunan yang menjadi masalah sejak persiapan lahan sampai dengan pemeliharaan tanaman menghasilkan. Pada tanaman kakao dewasa yang kondisinya baik, umumnya tajuk tanaman menutup rapat sehingga pertumbuhan gulma sangat tertekan. Hal ini bukan berarti masalah gulma pada tanaman kakao dewasa menjadi kurang penting. Kerugian yang ditimbulkan oleh gulma berbeda dengan kerugian akibat hama dan penyakit. Kerugian hama dan penyakit umumnya bersifat eksplosif, sedangkan kerugiankarenagulmabersifatrelatiftetap dan tidakpernah melonjak dengan tiba-tiba (Wahyudi dkk., 2008).

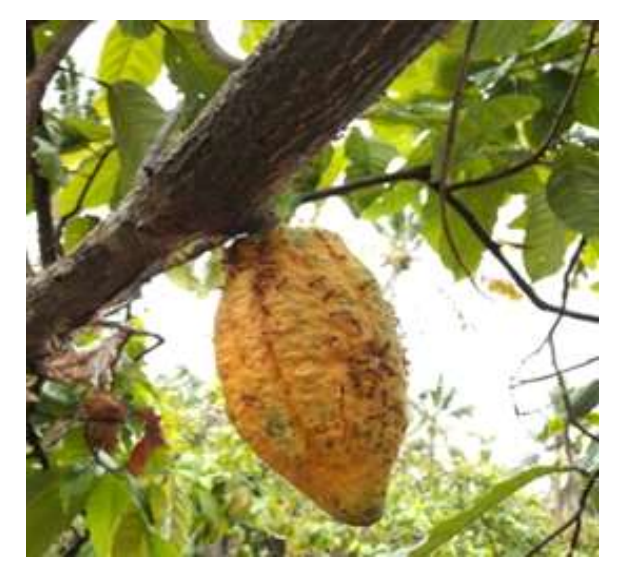

Gambar 4. Semut rangrang (Oecophylla smaragdina) pada buah kakao 
Di kecamatan Sukadana dilakukan pengamatan pada desa Banding dan Sukadana Selatan (Tabel 3). Hasil pengamatan kepadatan populasi di desa Banding dan Sukadana Selatan relatif sama sedangkan data intensitas kerusakan pada desa Sukadana Selatan lebih tinggi dibandingkan dengan desa Banding. Namun angka intensitas serangan ini tidak terlalu tinggi karena pada pertanaman kakao banyak dijumpai semut yang merupakan musuh alami dari Helopeltis sp. Semut hitam (Dolichoderus thoracicus) bisa dimanfaatkan sebagai pengendali perkembangbiakan Helopeltis sp. adanya kutu putih (pseudococcus sp.) pada buah maupun pucuk kakao mengundang berkerumunnya semut hitam pada tanaman kakao karena kandungan embun madu kutu putih. Penanaman kelapa sebagai pohon pelindung bisa menjadi sarang tetap semut hitam juga sangat baik untuk dikembangkan guna mengendalikan cahaya matahari (Siregar dkk., 2010). Semut hitam biasanya bersarang dan aktifbergerak pada pohon, cabang, daun, dan buah kakao, sehingga menyebabkan imago Helopeltis sp. tidak dapat makan dan meletakkan telurnya pada buah kakao, adanya semut yang terdapat pada buah kakao (Gambar 3).

Berdasarkan hasil penelitian Karmawati dkk,1999 dalam Atmadja, 2012 di Wonogiri telah ditemukan beberapa jenis predator $H$ antonii , yaitu Coccinella sp., semut hitam (Dolichoderus thoracicus ) dan semut merah ( Oecophylla smaragdina). Namun, populasi semut hitam dan semut rangrang lebih dominan. Keefektifan predator dalam mengendalikan $H$. antonii membutuhkan waktu sekitar dua tahun. Semut hitam (Dolichoderus thoracicus) dan semut merah ( Oecophylla smaragdina) mengganggu imago Helopeltis spp. pada permukaan buah menyebabkan Helopeltis tidak bisa meletakkan telur atau mengisap buah karena diserang oleh semut tersebut. Selain semut hitam, pada buah kakao juga dijumpai semut rangrang (Oecophylla smaragdina) yang berwarna merah kecoklatan (Gambar 4). Sama halnya dengan semut hitam semut rangrang juga sebagai predator pada tanaman kakao.

Pada kecamatan Sekampung Udik dilakukan pengamatan pada desa Mengandung Sari dan Bandar

Tabel 3. Kepadatan populasi dan intensitas serangan Helopeltis sp. pada tanaman kakao di Kecamatan Sukadana

\begin{tabular}{ccc}
\hline Desa & Kepadatan populasi (ekor/buah) & Intensitas serangan(\%) \\
\hline Banding & 0,02 & 17,83 \\
Sukadana Selatan & 0,10 & 26,17 \\
\hline
\end{tabular}

Tabel 4. Kepadatan populasi dan intensitas serangan Helopeltis sp. pada tanaman kakao di Kecamatan Sekampung Udik

\begin{tabular}{ccc}
\hline Desa & Kepadatan populasi (ekor/buah) & Intensitas serangan(\%) \\
\hline Mengandung Sari & 0,29 & 27,50 \\
Bandar Agung & 0,03 & 17,33 \\
\hline
\end{tabular}


Agung (Tabel4). Hasil pengamatan kepadatan populasi pada Desa Mengandung Sari dan Bandar Agung tidak relatif berbeda sedangkan intensitas kerusakan Desa Mengandung Sari lebih tinggi dibandingkan dengan Desa Banding. Hasil pengamatan Helopeltis sp. ini tergolong cukup rendah, karena pada areal pertanaman kakao tidak menggunakan pohon pelindung (naungan) sehingga kebun menjadi lebih terang dan tidak terlalu lembab. Pada umumnya Helopeltis sp. hidup pada kisaran suhu yang efektifadalah suhu minimum $15^{\circ} \mathrm{C}$, suhu optimum $25^{\circ} \mathrm{C}$, dan suhu maksimum $30^{\circ} \mathrm{C}$, sementara itu kelembaban juga merupakan faktor penting yang mempengaruhi kegiatan, dan perkembangan serangga. Dalam kelembaban yang sesuai serangga biasanya lebih tahan terhadap suhu ekstrim (Jumar, 2000 dalam Fitriani, 2015). Selain suhu, rendahnya kepadatan Helopeltis sp. yang didapatkan juga dipengaruhi oleh kelembaban lingkungan, kisaran kelembaban lingkungan yang diperoleh $80 \%-85 \%$, kisaran kelembaban ini termasuk tinggi. Menurut Susniahti dkk., 2005. Perkembangan Helopeltis sp. banyak dipengaruhi oleh keadaan iklim dan ketersediaan makanan. Pada umumnya keadaan cuaca yang panas dengan kelembaban relatif sekitar 70\%-80\% cocok bagi perkembangan Helopeltis sp. sehingga populasinya bertambah banyak.

\section{KESIMPULAN}

Kepadatan populasi Helopeltis sp. di Kecamatan Margatiga yaitu 0,19 ekor/buah, Kecamatan Sukadana 0,06 ekor/buah, dan di Kecamatan Sekampung Udik 0,16 ekor/buah.
Kepadatan populasi Helopeltis sp. di tiga kecamatan tersebut tidak berbeda nyata. Intensitas serangan buah kakao pada Kecamatan Margatiga yaitu 45,58\%, di Kecamatan sukadana 22,00\%, dan di Kecamatan Sekampung Udik 22,42\%. Intensitas kerusakan buah kakao di tiga kecamatan tersebut tidak berbeda nyata.

\section{DAFTAR PUSTAKA}

Anshary, A. 2009. Penggerek buah kakao, conomoporpha cramerella snellen (Teknik pengedaliannya yang ramah lingkungan). Jurusan hama dan penyakit tumbuhan, Fakultas Pertanian, Universitas Tadulako. Sulawesi. Jurnal Agroland 16 (4) : $264 \mathrm{hlm}$.

Atmadja, W.R. 2003. Status Helopeltis antonii sebagai hama Pada Beberapa Tanaman Perkebunan dan pengendaliannya. Bogor. Jurnal Litbang Pertanian, 22(2) : 57-63.

Atmaja, W. R. 2012. Pengendalian Helopeltis Secara Terpadu Pada Tanaman Pertanian. UnitPenerbitdan Publikasi Balitro. Bogor. $31 \mathrm{hlm}$.

Direktorat Jenderal Perkebunan. 2017. Statistik Perkebunan Indonesia . Direktorat Jenderal Perkebunan, Jakarta. 70 hlm.

Direktorat Jenderal Perkebunan. 2015. Statistik Perkebunan Indonesia 2014-2016 Kakao (Vol. 1). Direktorat Jenderal Perkebunan Indonesia. Jakarta. $58 \mathrm{Hlm}$.

Fitriani, W. 2015.Kepadatan populasi kepik penghisap buah (Helopeltis theivora) pada perkebunan kakao (Theobroma cacao L.) di Padang Mardani Kecamatan Lubuk Basung Kabupaten Agam. Sumatera Barat. E-Jurnal. 
Susniahti, N., Sumeno dan Sudarajat. 2005. Bahan Ajar Ilmu Hama Tumbuhan. Bandung: Universitas Padjadjaran.

Siregar, T.H.S., Slamet, R dan Laeli, N. 2010. Budidaya Cokelat. Penebar Swadaya. Jakarta. $178 \mathrm{hlm}$.

Siswanto, Muhamad, R., Omar, D., \& Karmawati, E. (2009). The effect of mating on the eggs fertilitiy and fecundity of Helopeltis antonii(Heteroptera: Miridae). Tropical Life Sciences Research, 20 (1) : 89-97.
Utami, A., Dadang., Nurmansyah, A., Laba I. W., 2017. Tingkat resistensi Helopeltis antoni (Hemiptera: Miridae) pada tanaman kakao terhadap tiga golongan pestisida sintesis. Institut Pertanian Bogor. Bogor. Jurnal Tanaman Industri dan Penyegar. 4(2):89-98.

Wahyudi, T., Panggabean dan Pujianto. 2008. Kakao Manajemen Agribisnis dari Hulu Hingga Hilir.Penebar Swadaya. Jakarta. $351 \mathrm{hlm}$. 